\title{
A BIT OF JUDICIAL HISTORY PERTAINING TO JASPER COUNTY, IOWA (93 YEARS)
}

\section{By Hentry Silwold}

A bit of curiosity about the question as to who had held the office of clerk of the District Court of Jasper County, Iowa, discussed recently between members of the local bar, has led to a little broader investigation into related matters.

By Section 9 of the Organic Law enacted by the Congress, June 12,1838, which constituted the territory of Iowa after July 3d of that year, it was provided that "The judicial power of the said territory shall be vested in a Supreme Court, district courts, probate courts and justices of the peace. The Supreme Court shall consist of a chief justice and two associate judges, any two of whom shall be a quorum, and who.shall hold a term at the seat of government of the territory annually; and they shall hold their offices during the term of four years. The said territory shall be divided into three judicial districts, and a District Court or courts shall be held in each of the three districts, by one of the judges of the Supreme Court, at such times and places as may be prescribed by law; and the said judges shall, after their appointment, respectively reside in the districts which shall be assigned to them." 'These district courts were both territorial courts and courts of the United States the same as our federal district courts of today, and the first six days of each term, or so much thereof as was necessary to transact their business as federal courts, was required to be used to dispose of such business as arose under the Constitution and laws of the United States. A marshal was provided to enforce the orders and judgments of these courts when functioning as federal courts. An attorney was provided for the territory to represent it (as an attorney general).

By Section.11 of the same act it was provided "that the ... chief justice and associate judges, attorney and marshal, shall be nominated, and, by and with the advice and consent of the Senate, appointed by the president of the United States." Section 7 of the act provides that the governor of the territory shall appoint the sheriffs by and with the consent of the Legis- 
lative Council (which occupied the place of the present state Senate).

The judges of the Supreme Court of the territory of Iowa thus constituted were Charles Mason of Burlington, Joseph Williams of Muscatine (then known as Bloomington), and Thomas S. Wilson of I Jubuque (then spelled Du Buque). Joseph Williams was judge of the Second Judicial District and the part of the country out of which Jasper County was carved was a part of that district. By Section 1 of Chapter 101 of the Acts of the territorial legislature, approved January 17, 1846, the then created Jasper County was specifically placed in that district. And it was in his capacity of district judge that said Joseph Williams is said to have wandered into Jasper County in the month of April, 1846, to hold a term of the District Court in the dwelling house of Matthew D. Springer, in what is now Buena Vista Township, as the territorial legislature had provided. Newton was not then on the map. There is no official record of any court proceedings having been had at this time; but a history of Jasper County published in 1878, when many of the pioneers were living, states that "A grand jury was summoned with some difficulty, for there were not over fifty voters in the county. Springer had built a temporary cabin the Fall before, in which he had wintered, and had just completed an addition to the structure, so that, considering the development of the county, he had ample room for court purposes. John A. Kinsman was appointed clerk of the court at this time."

A grand jury was impaneled and retired a few paces from the cabin so as to be by themselves, probably "deliberated" for a few minutes and returned to report "no bills found." No petit jury was summoned. In his instructions to the grand jury Judge Williams is said to have used this.language: "Gentlemen, in your deliberations you must not lose sight of the fact that Jasper County has no money yet. I would hint to you, also, that there are plenty of black hickories." The writer of the foregoing history seems to have been informed by an "eye witness," who thought that the judge meant to suggest that in case of larceny a judicious application of "hickory oil" would induce offenders te leave. The writer suspects that Ballinger Aydelott was probably the "eye witness."

By the act of the territorial legislature organizing Jasper 
County it was provided that Richard Fisher of Wapello County, E. M. Kirkham of Davis County and Thomas Henderson of Keokuk County should be the commissioners to locate the county seat of Jasper County. Two of them, Henderson and Fisher, appeared before Ballinger Aydelott, a justice of the peace, and took their oath to "faithfully and impartially locate the county seat according to the best interests of the county, taking account of the present as well as the future population of the county." On May 25, 1846, they filed their report with J. N. Kinsman, clerk of the District Court, in which office the document is preserved. This document reads :

Territory of Iowa, Jasper County:

The undersigned commissioners appointed By an Act of the Legislator of the Territory of Iowa, passed at the session of 1845-6, providing for the-organization of the Counties of Jasper and Polk Counties, after having been Duly qualified agreeably to the provisions of Said Act, faithfully and impartially to locate the Seat of Justice of said Jasper County and having examined the Situation of said County have Agreed, and doe hereby Locate and Establish the County Seat of said Jasper County on the northwest quarter of section (34) Thirtyfour, 'Township eighty (80), of Range nineteen (19). Witness our hands this 14th day of May, A. D. 1846,- and further Doe Give the Seat of Justice of said County the name of Newton City.

Thomas Henderson

Richard Fisher,

Commissioners to locate the Seat of Justice of Jasper County, Iowa Territory.

Section 1 of Article $V$ of the Constitution of 1846 provides: "The judicial power shall be vested in a Supreme Court, district courts and such inferior courts as the General Assembly may from time to time establish."

Section 2 of the same article provided: "The Supreme Court shall consist of a chief justice and two associates, two of whom shall be a quorum to hold court."

Section 3 of the same article provided: "The judges of the Supreme Court shall be elected by the joint vote of both branches of the General Assembly, and shall hold their courts at such time and place as the General Assembly may direct, and hold their office for six years, and until their successors are elected and qualified, and shall be ineligible to any other office during the term for which they may be elected. . .." 
Section 4 of the same article provided: "The District Court shall consist of a judge, who shall be elected by the qualified voters of the district in which he resides, at the township election, and hold office for the term of five years, and until his successor is elected and qualified, and shall be ineligible to any other office during the term for which he may be elected. ..." The township election was held on the first Monday in the month of April.

Section 3 of Article $V$ of the Constitution of 1857 requires that the judges of the Supreme Court shall be elected by the qualified electors of the state, and their term of office continues at $\operatorname{six}$ years. Section 1 of the same article provides that "The judicial power shall be vested in a Supreme Court, District Court, and such other courts, inferior to the Supreme Court, as the General Assembly may, from time to time, establish." Section 5 of the same article provides "The District Court shall consist of a single judge, who shall be elected by the qualified electors of the district in which he resides. The judge of the District Court shall hold his office for the term of four years, and until his successor is elected and qualified; and shall be ineligible to any other office, except that of judge of the Supreme Court, during the term for which he was elected."

Section 10 of the same article provides that "The state should be divided into eleven judicial districts." There were the further provisions that no legislature should increase the number of districts by more than one, and, of course, the number of judges conld be increased only by the one for the new district.

\section{Judicial Districts}

Under the Constitution of 1846 the First General Assembly, by Chapter 26 of its acts, approved February 4, 1847, Jasper County, with Johnson, Linn, Benton, Iowa, Polk, Poweshiek, Dallas, 'Tama, Marshall, Story, Boone, and all counties west, were created the Fourth Judicial District. And from other sources we learn that while Jasper County was a part of this district James P. Carlton of Iowa City was the judge. Terms of court were ordered held in Jasper County on the third Mondays of March and September of each year. As far as the court records reveal this judge held no court in Jasper County.

By Chapter 57 of the Acts of the Second General Assembly 
of Iowa, approved January 12, 1849, the legislature constituted the counties of Appanoose, Wayne, Decatur, Ringgold, Taylor, Page, Fremont, Monroe, Lucas, Clarke, Marion, Warren, Madison, Jasper, Polk, Dallas, Marshall, Story, and Boone, as the Fifth Judicial District. William McKay of Des Moines was elected judge of this district on the first Monday of April, 1849. Phineas M. Casady of Des Moines was elected his successor five years later but resigned to accept a more lucrative office. J. C. McFarland of Boonesboro was elected to fill the vacancy under constitutional and statutory provisions. A little local history of his official career is related elsewhere herein.

By Chapter 2 of the Acts of the Sixth General Assembly of Iowa, approved December 10, 1856, the counties of Jasper, Poweshiek, Mahaska, Marion, Polk, Dallas, and Madison were constituted the Eleventh Judicial District, and William M. Stone of Knoxville became the district judge of this district while it lasted. On March 20, 1858, the Seventh General Assembly of Iowa constituted the counties of Jasper, Marion, Poweshick, Mahaska, Keokuk, Washington, and Jefferson as the Sixth Judicial District. William M. Stone became the first judge of the new district. Other judges of the District Court of this district have been: William Loughridge of Oskaloosa, 1861-1866; Ezekiel S. Sampson of Sigourney, 1867-1874; Horace S. Winslow of Newton, 1875-1878; John C. Cook of Newton, 1879-1882; J. Kelly Johnson of Oskaloosa, 1883-1894; David Ryan of Newton, 1887-1898; William R. Lewis of Montezuma, 1887-1890; Almon R. Dewey of Washington, 1891-1902; Ben McCoy of Oskaloosa, 1895-1898; William G. Clements of Newton, 18991910; John T. Scott of Brooklyn, 1899-1906; Byron W. Preston of Oskaloosa, 1903-1912; Kleber E. Willcockson of Sigourney, 1907-1918; John F. Talbott of Brooklyn, 1911-1918; Henry Silwold of Newton, 1913-1918; Henry F. Wagner of Sigourney, 1919-1927; Charles A. Dewey of Washington, 1919-1928; Daniel W. Hamilton of Grinnell, 1919-; Frank Bechly of Montezuma, 1927-; James F. Patterson of Oskaloosa, 1928-. The last three are now serving.

By virtue of Article $V$ of the Constitution of 1857 requiring the District Court to consist of a single judge, and restricting the legislature to an increase of a single district and but a single 
judge in any one session, but authorizing the creation of a court inferior to the Supreme Court, the General Assembly in 1868 created the Circuit Court to consist of two circuit judges in each judicial district, the districts being divided into two circuits, with a judge elected for each circuit. Jasper County with Malaska and Marion counties composed the Second Circuit of the Sixth Judicial District. And these circuit judges were elected at the November, 1868, general election for terms of four years, their term as fixed by the legislature. This Circuit Court was given original jurisdiction in "all matters relating to the probate of wills, the appointment and supervision of executors, administrators, and guardians of minors, idiots, and lunatics, the settlement of decedents' estates, and the care of the estates of minors and insane persons, and all others under guardianship; and all proceedings for the examination or settlement of accounts of executors, administrators and guardians; all applications for the sale of real estate belonging to minors, or persons under guardianship; the issuing of marriage licenses; and all proceedings under Article I, Chapter 57 of the Revision of 1860, and of all other actions and proceedings of which the county judge or County Court now has jurisdiction." The court also was given concurrent jurisdiction with the District Court over enumerated matters. The same act abolished the County Court.

By the same statute the General Assembly also created what it was pleased to call General Term Courts, modeled after the New York system of courts; each of such courts to consist of the district judge and the two circuit judges of the judicial district. It was an intermediate appellate court. Judgments and decrees were taken to it for review from the district and circuit courts of the district, and from it appeals were taken to the Supreme Court. This court was required to hold not less than two; nor more than four "general terms" in the judicial district each year. This Gencral Term Court was in existence just a year and three months, as the next legislature abolished it and sent the appeals then pending in it direct to the Supreme Court by legislative fiat. After the abolishing of this court the number of circuit judges was decreased to one in each judicial district to be thereafter increased to meet the business necessities of 
any district. (See Chapter 22 of the Acts of the Fourteenth General Assembly.) By Chapter 19 of the Acts of the Twentieth General Assembly the Sixth Judicial District was again divided into two circuits and given two circuit judges, Jasper County being again put into the Second Circuit as originally when the Circuit Court was created. The Circuit Court was abolished by Chapter 134 of the Acts of the Twenty-first General Assembly in 1886.

The judges of the circuit who served the Sixth Judicial District as such were: Iucian C. Blanchard of Montezuma, 18691880 ; H. S. Winslow of Newton, 1869-1870; Stephen N. Lindley of Newton, 1871-1872; William R. Lewis of Montezuma, 1881-1886; John A. Hoffman of Oskaloosa, 1884; Geo. W. Crozier of Knoxville, 1885-1886.

\section{Prosecuting Atronneys}

Prosecuting attorneys under Section 7 of the Organic Law of the territory were appointed by the governor for each judicial district. By an act of the territorial legislature approved January 15, 1839, it was provided: "That there shall be a district prosecutor appointed by the governor, by and with the advice and consent of the Council, in each judicial district in this territory, who shall hold his office for two years, unless sooner removed, from and after his appointment." He was to take a prescribed oath and give bond in a penalty of five thousand dollars. Vacancies in the office were to be filled by the governor which appointment expired on the meeting of the next Legislative Assembly. The same act prescribed their duties and fixed their salaries at such a sum as the Board of County Commissioners "in each county should deem proper."

The foregoing provisions of the Organic Law were embodied in a statute enacted by the territorial legislature, approved January 15,1839 . By Chapter 18 of the act of the territorial legislature approved January 17, 1846, these prosecuting attorneys were absolved from giving bond. Chapter 58 of the Revised Statutes of the territory of 1843 , which is a codification of an act of the territorial legislature, approved January 15, 1839, continued the procedure of appointing district attorneys as provided in the Organic Law. Chapter 19 of the acts of the terri- 
torial legislature enacted (according to the reprint thereof) on January 17, 18:5 (should be 1846), provides: "That there shall be appointed by the governor, by and with the consent of the Council, a suitable person in each county, or organized district as hereinafter provided, to act as public prosecutor, who shall qualify in like manner as district prosecutors now are reiuired to by the act to which this is amendatory, and shall hold their offices for the term of two years unless sooner removed." By the third section of this act Jasper County came into what was the Tenth District with Keokuk County as the pivotal county.

The prosecuting attorney under the First Constitution was a county officer elected at the general election for a term of two years. (Article V, Section 5, of the Constitution of 1846.) According to Section 2, of Chapter 9 of the Acts of the First General Assembly of the state of Iowa they were required to give bond in a penalty of two thousand dollars and take an oath to faithfully perform the duties of the office.

Under the Constitution of 1857 the prosecuting attorney became a district officer again. Section 13 of Article $V$ of said Constitution provides that: "The qualified electors of each judicial district shall, at the time of the election of district judge, elect a district attorney, who shall be a resident of the district for which he is elected, and who shall hold his office for the term of four years, and until his successor shall have been elected and qualified." The legislation carrying out this provision is found in Chapter 25 of the Revision of 1860 , which was preceded by Chapter 102 of the Acts of the Seventh General Assembly.

By Amendinent 4, adopted in 1884 to the Constitution of the state of Iowa, it was provided: "That Section 13 of Article V of the Constitution be stricken therefrom, and the following adoptcd as such section: Section 13. 'The qualified electors of each county shall, at the general election in the year 1886, and every two years thereafter elect a county attorney, who shall be a resident of the county for which he is elected, and shall hold his office for two years, and until his successor shall have been elected and qualified."

We have found no record as to who the earlier prosecuting attorneys were. But somewhere in the past the writer picked up 
the bit of news that Geo. T. Anderson was the first county attorney of Jasper County under some of this "ancient" legislation.

The district attorneys who served the Sixth Judicial District by virtue of the legislation resulting from the constitutional provisions of 1857 were: George D. Woodin of Sigourney, Horace S. Winslow of Newton, Moses A. MeCoid of Fairfield, S. G. Smith of Newton, George W. Lafferty of Oskaloosa; Edward W. Stone of Washington, and John A. Donnell of Sigourney.

Under legislation carrying into effect the constitutional amendment of 1884 creating the office of county attorney the following men have served Jasper County as county attorney: Adams M. Harrah, William G. Clements, Edward J. Salmon, Alanson Clark, Oliver C. Meredith, William O. McEIroy, Henry Silwold, Phineas M. Cragin, Edward P. Malmberg, Ross R. Mowry, Marion R. Hammer, Jr., D. M. Tripp, Hugo C. Schulz, George E. Campbell, Alfred M. Miller.

As has already appeared Section 9 of the Organic Law provided that there should be a Probate Court. An act of the first territorial legislature, approved January 17, 1839, created such probate courts. It provided that the court should be a court of record, the jurisdiction thereof coextensive with the county, some fit person should be appointed the judge thereof. It is not stated by whom the appointment should be made, but presumably by the legislature, as the governor could appoint to fill a vacancy during the recess of the Legislative Assembly. This court had jurisdiction of the usual business pertaining to the settling of estates of deceased persons, of guardianships and kindred subjects. The term of office was three years. The court was required to be held on the first Monday of each month and continue until the business before it was disposed of. Appeal from its decisions was taken to the District Court, and from there to the Supreme Court. By Section 5 of Chapter 109 of the Acts of the First General Assembly of the state of Iowa, it was provided that a probate judge should be elected for each county on the first Monday of August in the year 1847 and biennially thereafter. By Chapter 20 of the Acts of the Third General Assembly John H. Franklin was authorized to transcribe the records of the Probate Court of the county, and to 
receive for such work eight cents per hundred words transcribed. Whether these records were in fact ever transcribed we do not know. But it is quite apparent that a transcribing of some of the early records of the courts of the county is very much needed. By Chapter 240 of the Code of 1851 the office of probate judge was abolished. By Chapter 24 of the Code of 185.1, of which the statute last cited is a part, the offices of county commissioners and their clerk were also abolished. By this statute the office of county judge was created, and given jurisdiction of the business theretofore transacted by the county commissioners and their clerk as well as the probate business of the county. The probate records were required to be kept in books separate from those relating to the other business of the court. The judge of this new court was elected for a term of four years, and when he had taken office he had, under the then law of the state, all the powers of the present Minister of Foreign Relations of the Kingdom of Italy.

The judges of the various probate courts from the first, when the state was but a territory, until the end of the year 1868, when the County Court was abolished and the jurisdiction of the probate business and kindred subjects transferred to the newly created Circuit Court, were John H. Franklin, Washington Fleenor, Jesse Rickman, David Harris, W. P. Norris, David E.dmundson, J. W. Wilson, M. A. Blanchard, R. I.inderman, J. A. Harris, and O. C. Howe.

The first case which came into the Probate Court of Jasper County was the will of Henry W. Adamson filed in the office of John H. Franklin, probate judge, and by that official admitted to probate on October 19,1846 , while Iowa was yet a territory.

The first case of guardianship was that of Adam W. Maggart, a minor over fourteen years old. The record reads as follows:

Territory of Iowa,

Jasper County, $\}$ ss:

At a regular. Term of the Probate Court in and for said county, begun and holden on the Ist day of February, A. D. 1847. [You sec the judge had not discovered that the territory had ceased on December 28,1846 , or he would have made a different heading.] Personally appeared before me on the day aforesaid Adam W. Maggart a minor above the age of fourteen years, who proceded to make choice of Elenor Maggart his mother to be his Guardian who was accordingly 
appointed by said Court and Letters of Guardianship was granted and al bond taken for her performance as such Guardian. Said Bond recorded on the following page.

The letters follow the above record.

The sccond will case was that of Elisha Hammer, which had been executed on May 15, 1847. It was admitted to probate June 7, 18:7. The will clearly evinces an effort on the part of the testator to do justly by his widow and nine children and some grandchildren.

The next probate case is that of the last will and testament of Blakely Shoemake which was admitted to probate on November 22, 1848. No executor was named in the will so the widow, Mercy Shoemake, was appointed administratrix with the will annexed.

The next case of guardianship was that of Luther Shoemake, who having arrived at the age of sixteen years the probate judge had the sheriff of the county serve him with a notice requiring the said minor to appear before the court to make choice of his guardian on the first Monday in June, 1849.

By Amendment No. 2, one of the amendments to the state Constitution adopted in 1884, it is provided: "At any regular session of the General Assembly, the state may be divided into the necessary judicial districts, for district court purposes, or the said districts may be reorganized and the number of districts and the judges of said courts increased or diminished; but no reorganization of the districts or diminution of the judges shall have the effect of removing a judge from office." By virtue of this constitutional provision, by Section 3 of Chapter 134 of the Acts of the Twenty-first General Assembly, the state was divided into eighteen judicial districts, all the districts except the Eighth and Seventeenth having more than one judge; the Sixth Judicial District as constituted by the chapter was given three district judges. As elsewhere stated this same act abolished the Circuit Court. Section 8 of the chapter reads thus: "All the rights, powers and jurisdiction now by law belonging to or vested in, or exercised by the Circuit Court shall upon and after the first day of January, 1887, be transferred to, conferred upon and exercised by the District Court; and all causes, proceedings, and remedies of every kind pending or undetermined 
in the Circuit Court at said date shall stand for trial or other disposition in the District Court as if originally brought therein."

This legislation made the District Court the "probate court" of the state. And elsewhere in the same statute the clerk of the District Court was vested with power to transact some of the work formerly done by the probate judge.

\section{Grand JuRY}

The Grand Jury at first consisted of twenty-three persons as in the federal courts. The number has been gradually reduced since then. Amendment 3 to the Constitution of 1884 provides: "The Grand Jury may consist of any number not less than five, nor more than fifteen, as the General Assembly may by law provide, or the General Assembly may provide for holding persons to answer for any criminal offense without the intervention of a Grand Jury." This constitutional provision, under suitable stacutory enactments, has given us a Grand Jury of seven members, and also the "County Attorney's Information."

By the sixth subdivision of Section 3, of Chapter 134 of the Acts of the Twenty-first General Assembly, approved April 10, 1886, the Sixth Judicial District was reorganized and the counties of Marion and Jefferson removed from the roster of counties composing the district, and the county of Louisa added. This act took effect January 1, 1887 .

By Section 1 of Chapter 121 of the Acts of the Twenty-sixth General Assembly of Iowa Louisa County was severed from the Sixth District and joined with Des Moines and Henry counties to form the Twentieth Judicial District. Since that time the counties of Jasper, Poweshiek, Mahaska, Keokuk and Washington compose the Sixth Judicial District. The last legislative act above referred to went into effect May 9, 1896.

\section{Court Houses}

In 1847 the first Court House was built in Newton at a cost of $\$ 262.50$. We arrive at this from the facts that on January 5, 1847, Evan Adamson was voted $\$ 87.50$ for building the same, and on July 6th following he was voted the further sum of $\$ 175.00$ by the county commissioners, and the building accepted. It did not occupy the present site, but stood on the block just 
off the public square and cornering with it at the northwest corner.

The necessity for increased accommodations for the county offices had been felt for some time, but in 1857 the need became imperative. So the county judge entered into a contract with one John Hyde to construct a foundation for a new Court House in the center of the public square, to carry a building which should be ample for many years. On October 30, 1858, the county judge ordered $\$ 1,981.43$ paid to Hyde on his contract, and adds that "this completes the sum of $\$ 26,600.00$ which has been paid on the Court House, and for which J. P. Huskins, agent of John Hyde, the contractor, has receipted for as payment in full for contract, and all extras in or about said building; the house is therefore received from the hand of the contractor." The building was a classical piece of architecture until later necessity of the county for additional rooms made necessary additions which destroyed the original plan and design. But we were then a utilitarian people and beauty, even in a public building, was not considered, nay, not for a moment.

Sometime in 1905 some of the people of Jasper County commenced talking about building a new Court House. This talk was most pronounced in and about Newton. But Colfax, Prairie City, Monroe and other outlying territory could see little merit in this propaganda. The proposition was submitted to the voters of the county and on October 17, 1905, it was defeated by a vote of 1,736 for to 2,311 against the proposition. It was submitted a second time and at the general election in November, 1906, the proposition to build a new Court House was defeated by 2,463 yes to 3,100 no.

After being thus twice defeated at the polls the proposition to build a new Court House was at last carried on November 3, 1908 , by a vote of 3,158 for the proposition and 2,817 votes against it. Proudfoot \& Bird were the architects, and Jas. Rowson \& Son were the contractors. The contract was let February 18, 1909, work on the project began April 1, 1909, and the building was completed April 6, 1911. The building is 120 feet and 8 inches long, 80 feet wide, and is 56 feet from the grade line to the cornice, the tower rises 56 feet above the roof and the top of the flag pole is 140 feet from the ground. The struc- 
ture is built entirely of cut Bedford limestone, lined with brick. All girders are steel and floor and roof are of fire proof material. Only the doors and window casings are wood. It is a good building and when planned was supposed to be ample for the demands of the county for many years to come. Probably the greatest mistake made at the time of its erection was that a full basement was not excavated and reserved for future use. Such a basement could now be used to very good advantage for minor, and even principal office quarters. But such forward vision was denied to both the architect who planned, and to the Board of Supervisors who had to provide for the erection of the building. The structure in 1909 to 1911 cost $\$ 200,225.71$.

It was said at the dedication of the building that "The rotunda is the glory of the building. From the mosaic seal of Jasper County in the floor, done in ceramic tile of many colors, to the vaulted ceiling of art glass with the beautiful light of day shining down through the blending of exquisite tints, is a dream of beauty. The sixteen columns of matched marble-eight on each floor-are a delight to any eye which can discern artistic effects. The columns on the first floor are of the plainer Doric order of architecture and those above the more graceful and ornate Ionic.

"There are four emblematic oil paintings by Edgar Cameron of Chicago, each illustrative of some incident in the county's history. On the west is a wartime scene in the public square of Newton, with the old Court House in the center and soldicr boys leaving for the front, in Civil War days; on the south a prairie fire and a herd of buffalo; on the east a group of Uncle Sam's soldiers who camped on the banks of the Skunk River west of Newton in the early forties, and on the north the departing Indian and the coming of the white man."

It is to be hoped that in the not far distant future architects will abandon the idea that a court room is a suitable place for the display of ideas of beauty in architecture, and to substitute for this misplaced ambition the better one, to make a court room primarily a place in which to transact important public business comfortably and with ease. In other words, the court room in this otherwise fine building, is an abomination as far as acoustics is concerned. 


\section{Sheriffes}

By Section 7 of the Organic Law the governor was directed to appoint the sheriff of the county. Since February 15, 1844, the sheriff has been an elective officer and his term of office two years, Congress by amendment to the Organic Law having made this possible, and he was ineligible for more than two successive terms in six years. If a vacancy happened it could only be filled by a special election. He was quite frequently the collector of taxes in addition to the usual duties of the office of sheriff.

\section{Divorces}

In our territorial days the legislature and not the courts granted divorces. Chapter 17 of the session of the territorial legislature of 1843 presents a bit of wholesale divorcing, in that this act did divorce nineteen husbands and wives. It was sent to the governor and by him returned with his objections thereto. After reconsideration by the Legislative Assembly the bill passed over the veto by a majority of two-thirds, and became a law February 16, 1843. Upon careful search of the work of the territorial legislature I am unable to say that any Jasper County parties were thus divorced.

\section{Dower}

The surviving spouse under Iowa law has had an estate in fee simple in the real estate left by the owner at his death, except during the time intervening betwen July 1, 1853, to April 18, 1862, when the statute of "dower at common law" prevailed in this state, which gave the survivor an estate for life only.

\section{Court Incidents}

We might as well interpolate a little court scene here which transpired locally in April, 1855. Phineas M. Casady who had been elected at the election for the purpose of electing district judges had resigned to accept a more lucrative office at the hands of the federal government. Thereupon J. C. McFarland of Boonesboro had become a candidate to succeed Judge Casady, and in his quest had been opposed by a member of the local bar, Harvey J. Skiff. So when Judge McFarland came to Newton to hold the April, A. D., 1855, term of the District Court, Mr. Skiff called up some case in which he appeared as attorney for 
one of the parties to have some simple order made. Whereupon the Judge peremptorily ordered him to be seated. But Skiff insisted that he and his client had some rights which the court ought to respect. But Skiff was repeatedly ordered to be seated, but kept standing on his rights as well as on his feet. Thereupon the court fined Skiff for contempt of court, which elicited further remarks from Skiff, and which remarks in turn drew a further fine from the court. The following morning, after consultation at Skiff's home the night before, the entire bar proceeded to continue all their cases. The Judge is said to have caught the drift of the situation and headed off the lawyers by adjourning court without day.

In the opinion in the case of Skiff $v s$. The State of Iotva, reported at page 550 of Volume II of the Iozva Reports we get the following from the transcript sent up by the clerk of the District Court: "Harvey J. Skiff fined for contempt of court fifty dollars. For a second contempt, fined one hundred dollars. Mittimus issued to sheriff of Polk County, to confine said H. J. Skiff, in the jail of said county for three days." This was all the record made. 'Too much of the elixir of corn which had gotten into the system of the Judge was responsible for the meager record made by him at the time, and was responsible for a reversal of the case without more. Chief Justice Wright saying in the opinion: "To fine and imprison the citizen, upon a record so barren and destitute of every legal requisite as the one before us, cannot be tolerated in this country where liberty and property are justly held so sacred." This was the Harvey J. Skiff whose name appears as the twenty-sixth signer of the Constitution of Iowa, adopted at Iowa City, on March 5, 1857, where he represented a district composed of Jasper, Poweshiek, Marshall, and Tama counties, where he gave his occupation as that of a banker, and who later operated the Skiff Drug Store in Newton, Iowa.

The foregoing related the story of an incident of the dim and distant past, when Iowa was the frontier. But Jasper County can show a few situations of a "more advanced civilization." As recently as about 1901 court was in session in Newton, likewise was the grand jury. At the suggestion of the county attorney subpoenas were prepared and served on some of Newton's 
"best citizens," requiring them to appear before that august body and tell what they knew about violations of law in Jasper County. When the first witness came he was asked what kind of liquor and when, he had bought of a Mr. X. When this witness had left the room word was gotten to Mr. X. by the grand jury that if he did not get twelve bottles of good cold beer to their room in a very short time he would be indicted. Shortly thereafter the beer is said to have arrived, and the clerk of this grand jury was by the grand jurors invited to help them dispose of the beer in the usual way. Need it be said that Mr. X. was not indicted? It is quite proper to state here that the clerk of the grand jury conscientiously for twenty-seven years observed the oath which he had taken as such clerk which reads: "that he would faithfully and impartially perform the duties of clerk of the grand jury, that he would not reveal to any one its proceedings or the testimony given before it and would abstain from expressing any opinion upon any question before it." After this lapse of time he did reveal the incident to the then county attorney, who happened to be the writer.

One more incident. A sister had sued her brother on a claim for money loaned. He defended, denying the debt. She was a witness in her own behalf. Her brother's attorney asked her on cross-examination why she had not pressed her claim sooner, it being one of long standing, whereupon she retorted, "You do not go to a goat's house for wool." 'This answer completely overwhelmed defendant's attorney and he excused the witness. Her own attorney likewise excused her, but she kept on talking. Both lawyers begged the court to shut off the flow of words. Judge Preston, who was holding that term of court, said to her, "Madam, you are excused!" Whereupon she left the witness chair, walking toward the door of the court room, but continued to talk until the door closed behind her. The two lawyers and the judge heaved a sigh of relief. When lo, she opened the door, stuck her head into the room and exclaimed, "There, I told you I would get the last word!"

\section{Clenks of the District Court}

Clerks of the District Court were at first appointed by the courts for which they became clerk, under Section 9 of the Or- 
ganic Law of the territory. And a judge in vacation was authorized to fill a vacancy in the office which appointment was operative only until the next term of the court. Thus it happened that when Judge Williams of Muscatine came to Jasper County to hold a term of court on the second Monday in the month of April (to be exact, April 13, 1846, while Iowa was still a territory) he appointed John A. Kinsman clerk of the court, and it was with this official that the document was filed locating the "Seat of Justice of said Jasper County," on May 25, 1846. He erected the first building in Newton City before the end of 1846, on lots one and two of block twenty-one, and it may very well be that there was established the first office of the clerk of the District Court of Jasper County, Iowa. He must have resigned for in April, 1847, Thomas J. Adamson was elected clerk to fill vacancy. The territory had become a state and under the Constitution adopted in 1846 the clerk of the District Court was elected by the voters of the county. (See Section 5 of Article VI of the Constitution of 1846.)

Peter Miller was elected clerk at the August election in 1848 and his bond as such officer approved on the tenth day of the same month. From then on we have the following record:

William M. Springer was elected in 1850 , and served one term.

W. P. Norris was elected in 1852, and served one term.

Charles C. Turner was elected in 1854, and served one term.

J. B. Hough (father of Emerson Hough) was elected in 1856 , and served two terms.

Owen Davis was elected in 1860 , and served two terms.

John A. Seaton was elected in 1864, and served two terms.

William R. McCullough was elected in 1868, and served four terms.

Lee B. Westbrook was elected in 1876 , and served two terms.

M. P. Doud was elected in 1880 , and served two terms.

Geo. W. Harlan was elected in 1884, and served two terms.

Nathaniel. Townsend was elected in 1888 , and served two terms.

John I. Matthews was elected in 1892, and served two terms.

Jake A. Mattern was elected in 1896 , and served one term.

C. H. Kapple was elected in 1898, and served one term. 
J. A. Mattern was elected in 1900, and served one term.

Ernest L. Early was elected in 1902, and served two terms.

P. H. Healey was elected in 1906, and served two terms.

Frank Wilson was elected in 1910, and served until December 24, 1925, when he died.

H. F. Cassidy was appointed to fill the vacancy caused by the death of Frank Wilson, was thereafter nominated and elected, and is the present clerk.

The early clerks of the District Court were ex-officio clerks of the Circuit Court and also of the Probate Court while these several courts were in existence. Although the law provided that the probate judge, if he saw fit, could act as his own clerk.

One of the duties of the clerk of the District Court in territorial days was to issue certificates of authority to ministers of the gospel to solemnize marriages. One James F. New seems to have obtained such a certificate from the clerk of the District Court in Lee County, Iowa Territory. His credentials were those of the Methodist church. A copy of the certificate was filed for record in the office of the clerk of the District Court of Jasper County, Iowa, on August 3, 1849. He makes return to said office on the same day that on July 5, 1849, he had "united in the bonds of matrimony in Jasper County, Iowa, Jesse Hammer and Margaret Sparks."

We are tempted to present the next Certificate of Authority in full. It reads thus:

State of Iowa,
Jasper County, ss:

The United States of America, Greeting: This may certify that the Claiborne Hiall has presented to ortered of being a regular Liesed Minister of the Gospel in connexion with the Christian Church therefore know yea that the said Claiborne Hall is hereby authorized to Solemnize the rites of Matrimony in said county of Jasper So long as he maintains his Standing in Said Church and no longer.

In testimony whereof $I$ have hereunto set my hand and affixed the seal of the District Court at Newton, Jasper County, Iowa.-Peter Miller, Clerk.

This instrument was recorded on August 10, 1849, so that is probably the date of it. This certificate was not issued in vain. For on the first day of September, 1849, Mr. Hall makes return that "on the sixteenth day of August 1849, at the house of 
Amanda Tice in said county I Solemnized the rites of Matrimony between Mr. Alexander McCollom aged twenty nine years, and Mrs. Amanda Tice aged twenty-six years."

The first lawyer in Newton and in Jasper County, was Johnson N. Edgar, with whose name abstracters are quite familiar owing to the fact that his name appears so frequently in early transfers of real estate.

Before its organization as a separate county Jasper County was attached to Mahaska County for election, revenue and judicial purposes by Section 17 of Chapter 68 of the Acts of the territorial legislature of Iowa, approved February 5, 1844. The whole county as so attached to Mahaska County was known as Washington Township.

Jasper County was established as a separate county and the boundaries of it prescribed by Chapter 83 of the Acts of the territorial legislature of Iowa, approved January 17, 1846, and have always remained the same. The county was "organized" by the same legislature in Chapter 101, approved on the same day, the organization to take effect March 1, 1846. The people of the county were authorized to hold their first election as a separate county, to choose county officers on the first Monday in the month of April, 1846.

Thus we have given a brief history appertaining to the courts and their work affecting Jasper County from the beginning to the present day. Many interesting incidents lie dormant in the records that could be culled therefrom to represent the now ancient history of the county, but they are not strictly germain to what is here intended. It is hoped by the writer that the effort, which has been a pleasant one, may prove interesting as well as informing to possible readers.

Newton, Iowa, July 1, 1931. 
Copyright of Annals of Iowa is the property of State of Iowa, by \& through the State Historical Society of Iowa and its content may not be copied or emailed to multiple sites or posted to a listserv without the copyright holder's express written permission. However, users may print, download, or email articles for individual use. 